\title{
A concepção mítica perpetuada no sertão de Inhamuns: uma leitura do espaço e do tempo no conto "A espera da volante", de Ronaldo Correia de Brito
}

\author{
Érica Alves Rossi \\ Universidade Federal de Mato Grosso do Sul (UFMS), Três Lagoas, Mato Grosso do Sul, Brasil \\ erica_a_rossi@yahoo.com.br
}

DOI: http://dx.doi.org/10.21165/el.v46i3.1562

\section{Resumo}

O presente artigo faz uma análise do conto "A espera da volante", de Ronaldo Correia de Brito, publicado no livro Faca (2009), a partir das categorias narrativas de espaço e de tempo e seu engendramento na construção das personagens. Buscou-se compreender como as três categorias, aliando-se a uma concepção mítica, filiam tal produção a uma compreensão do sertão consagrada com Guimarães Rosa, ao mesmo tempo em que se mostra contemporânea à nova ficção regionalista brasileira.

Palavras-chave: Ronaldo Correia de Brito; regionalismo; conto; espaço; mito.

The mythical conception perpetuated in the hinterland of Inhamuns: a reading of the setting in the short story "A espera da volante," written by Ronaldo Correia de Brito

\begin{abstract}
This article is an analysis of the short story "A espera da volante", written by Ronaldo Correia de Brito and published in the book Faca (2003) from space and time stories and their production in the construction of the characters. Another goal is to understand how the three categories combining with a mythical conception, affiliate this short story to an understanding of hinterland presented by Guimarães Rosa, while it shows the new contemporary Brazilian regionalist fiction.
\end{abstract}

Keywords: Ronaldo Correia de Brito; regionalism; short story; setting; myth.

\section{Introdução}

Os desmandos de autoridades locais em espaços desfavorecidos no Brasil não são surpreendentes, tampouco uma prática recente. O que dizer de regiões distantes dos centros urbanos, como o sertão nordestino, nas quais historicamente o Estado se faz ausente e a população se vê massacrada por todos os lados? No conto "A espera da volante", do cearense Ronaldo Correia de Brito, o protagonista encontra-se exposto aos excessos de forças policiais que se presentificam na diegese por uma tensão do porvir. Porém, mais do que uma narrativa que se atém a descrever uma realidade histórica, a produção se desenrola em um tempo e em um espaço míticos, que dimensionam a escrita para a tradição oral e para uma discussão sobre a própria condição humana.

Buscando estabelecer uma vertente analítica para o conto, partimos da perspectiva de sua estruturação por tal pensamento mítico, o que determina o tratamento dado ao tempo, ao espaço e, dentre as personagens, especialmente ao protagonista, emblematicamente o único não nomeado na narrativa. Procedendo à contextualização 
do movimento regionalista e do espaço ficcional do sertão, analisaremos o espaço e as personagens, que estão em íntima ligação construtiva, seguidos da discussão sobre a categoria do tempo, em vários momentos interpenetrada na análise inicial.

\section{Regionalista, eu?}

Embora critique o título, Ronaldo Correia de Brito é apontado como escritor regionalista. Sua postura, na verdade, dialoga com uma tendência de desvalorização do termo, advinda de escritores contemporâneos e também de críticos literários. Em artigo sobre o tema, Rodrigues e Grácia-Rodrigues (2013) percorrem a trajetória da ficção regionalista no Brasil e destacam como, desde o romantismo, a literatura intitulada regionalista nasce como parte de um programa literário em busca de uma autêntica literatura brasileira até chegar à rejeição em nossos dias:

[...] no romantismo, trata do típico, do pitoresco da região, da ação humana traçada pelo arquétipo patriarcal; no realismo, a proposta regionalista se firma; no modernismo dos anos 30, de estética realista, sua feição inicial atinge o ápice; em seguida, o termo é ressemantizado, para acolher nova literariedade que emerge com a obra de Guimarães Rosa, e então o termo mergulha em descrédito, sendo alienado, considerado indesejável por autores e crítica (RODRIGUES; GRÁCIA-RODRIGUES, 2013, p. 286).

Leonel e Segatto (2010, p. 1035) assinalam que a noção de regionalismo foi introduzida no século XIX para caracterizar a literatura produzida fora do Rio de Janeiro, nas províncias, que tinha como matéria a representação de locais remotos do interior - sobretudo o sertão - e seus respectivos tipos, relações sociais e humanas, paisagens, linguagens, identidades, imaginário. Por ser um conceito abrangente, passou a englobar diferentes autores e obras, de regiões e períodos históricos também distintos, o que levou ao nivelamento de composições de valor estético-literário desigual. Questionando-se sobre a razão do surgimento e da permanência histórica dessas manifestações, os autores apresentam como hipótese o fato de ser o Brasil "um estado nacional inconcluso, cuja unidade territorial e política foi imposta de cima, arbitrariamente, pela coação e com alta centralização no centro-sul"; com escassos elementos identitários, "temos a existência de regiões com realidades socioeconômicas e culturais muito diferenciadas” (LEONEL; SEGATTO, 2010, p. 1036).

Ao ser questionado sobre sua recusa a tal classificação, Brito (2005) mostra não lhe agradar que sua escrita seja comparada ao romance regionalista dos anos 1930. Tal vertente - que representa a culminância de um longo processo de descobrimento da realidade brasileira, influenciada pelos novos rumos das ciências naturais, colocadas em voga nas três últimas décadas do século XIX - destaca-se por suas produções assinalarem um Brasil que passa a ser visto por um ângulo de observação mais lúcido e crítico, assumindo, no campo da criação romanesca, caráter histórico e concreto, marcado, principalmente, por expor a miséria humana da população sertaneja e as mazelas das relações sociais e de poder (ALMEIDA, 2013). Em entrevista ao jornal $O$ Povo, ele salienta sua insatisfação com a postura da crítica frente aos autores que se mantiveram tratando do universo do sertão. Segundo Brito (2005), depois do romance de 30 , os artistas que se mantiveram tratando de sua geografia como cenário vivem uma espécie de condenação: "se você elabora uma personagem complexamente neurótica, feminista, com todos os anseios urbanos, e se você senta esta mulher numa cadeira de 
couro, olhando uma paisagem desolada do sertão, há quem enxergue apenas o cenário, e três ou quatro substantivos locais".

O que, então, diferenciaria a obra de Brito das ditas historicamente regionalistas? Qual carga contemporânea o autor imprime a seus textos que dialoga com uma nova tendência literária brasileira? Podemos iniciar tal discussão refletindo sobre o próprio conceito de contemporâneo a nós apresentado pelo filósofo Giorgio Agamben.

Para Agamben (2009), o contemporâneo é o intempestivo; pertence verdadeiramente ao seu tempo que não coincide perfeitamente com este, criando uma espécie de anacronismo e, justamente por isso, capaz de percebê-lo e apreendê-lo. É aquele que fixa seu olhar no seu tempo, mas que sabe ver sua obscuridade, interpelandoa, pois não se cega pela luz. A experiência simultânea de temporalidades diferentes, a visão do moderno tangenciando com o arcaico - no sentido de origem - é também sua habilidade: "somente quem percebe no mais moderno e recente os índices e as assinaturas do arcaico pode dele ser contemporâneo" (AGAMBEN, 2009, p. 69).

Schollhammer (2009) mapeia as últimas gerações de escritores brasileiros e, ao apresentar a geração de 1990 a 2000, cita Ronaldo Correia de Brito. Sem desconsiderar a diversidade entre os escritores, reconhece algumas características a eles comuns, como a preferência pela prosa curta, a intensificação do hibridismo literário e, em especial, o convívio entre a continuação de elementos específicos, que teriam emergido nas décadas anteriores, e uma retomada inovadora de certas formas e temas da década de 1970, destacando a sobrevivência do realismo regionalista, fortalecendo-se mesmo com ataques sofridos a ele. Esclarece que o realismo presente na nova geração de escritores não significa volta às técnicas de verossimilhança descritiva e de objetividade narrativa e, sim, a vontade ou o projeto explícito de retratar a realidade atual da sociedade brasileira, frequentemente pelos pontos de vista marginais ou periféricos, movido, hoje, "pelo desejo de realizar o aspecto performático e transformador da linguagem e da expressão artística, privilegiando o efeito afetivo e sensível em detrimento da questão representativa" (SCHOLLHAMMER, 2009, p. 57).

A forma de articular realidade e representação é um dos aspectos que filia Brito à contemporaneidade de que nos falam Agamben (2009) e Schollhammer (2009). Sua prosa integra visão aguda do real e interferência do mítico. O sertão que nos apresenta em "A espera da volante" traz-nos temporalidades simultâneas que desenham um universo singular, além da realidade presente e suas mazelas, interpelando sua obscuridade, dialogando com o arcaico, elemento constituinte do espaço e das personagens. Seu modo de retratar o sertão vem lhe rendendo estudos que o aproximam de Guimarães Rosa.

Em artigo no qual analisam o sertão literário nos dois autores, Leonel e Segatto (2010, p. 1040) reconhecem o viés regionalista que os liga, assim como a descrição, em suas obras, da violência, marcada pela ausência de representantes das instituições do Estado. Destacam algumas características da prosa do escritor cearense, sendo elas: brevidade das frases, muitas lapidares, linguagem sintética, direta e incisiva, com efeito, por vezes, de corte de lâmina, andamento prosaico, objetividade da linguagem, o que os faz distanciá-la da escrita barroca de Rosa e aproximá-la, por sua vez, da de Graciliano Ramos. Santos (2014) destaca, na produção de Brito, influências da literatura clássica, das narrativas bíblicas e também da tradição oral da cultura popular nordestina que retratam, por meio de suas histórias, o viver humano em seus mais diversos dilemas: o 
medo, o amor, a vingança, os remorsos, a loucura, as traições e, sobretudo, a morte. Um dos seus destaques seria a capacidade de demonstrar que, da realidade sertaneja, pode-se depreender uma espécie de essencialidade trágica do ser humano. A apresentação do livro que o conto integra traz-nos a dimensão de como tais aspectos surgem na prosa do autor.

\section{Faca: o sertão trágico e a força do feminino}

O conto "A espera da volante" está inserido no livro intitulado Faca, com primeira edição em 2003. O volume é composto de 11 contos curtos, cujo cenário vincula-se à sua terra natal, marcados, como o próprio título sugere, pela forte presença da violência e da morte, voltados, sobretudo, para o drama familiar sertanejo. Em posfácio para a obra, Davi Arrigucci Júnior destaca o feitio seco e depurado da prosa do escritor cearense e um peso decisivo que atribui ao tempo de espera, convertendo-o em um fator estrutural de suas histórias. Embora o narrador se apresente, segundo o crítico, acentuadamente comedido, dá vazão às reminiscências da tradição oral, marcada por um tempo cíclico, da natureza, que funciona como "uma espécie de condenação à recorrência, uma volta ao mesmo, que rege os destinos narrados e funciona como princípio de composição" (ARRIGUCCI apud BRITO, 2009, p. 174).

Outra recorrência é a construção de personagens femininas fortes, localizadas no sertão cearense, mas vivendo dramas universais. Santos (2014) defende que a obra está centrada no seguinte tripé de composição: o sertão, o trágico e a força da presença feminina. O trágico, aqui entendido como adjetivo para designar destinos fáticos de caráter bem definido, faz-se presente ao se retratar personagens dilaceradas pela "solidão, abandono, parricídios, matricídios, enfim, homens e mulheres inseridos numa existência movida, especialmente, por ódio, dor, sofrimento e vingança." (SANTOS, 2014, p. 13). "A espera da volante" traz o elemento trágico em sua composição. A morte está presente no conto, mas a tragédia anunciada logo no início da narrativa não se realiza na diegese, presentificando-se apenas por meio da tensão advinda da espera pela chegada violenta da volante policial.

\section{O sertão é o mundo}

Dialogando com uma tradição literária brasileira regionalista, o autor constrói seu universo ficcional na geografia do sertão. O espaço privilegiado por Brito é denominado de Inhamuns, região localizada na fronteira oeste do estado do Ceará, em pleno semiárido, geologicamente denominada de depressão sertaneja. É formado por um conjunto de municípios: Aiuaba, Tauá, Arneiroz, Parambu, Catarina e Saboeiro (SANTOS, 2014, p. 12). Mais do que explorar geograficamente a região, encontra-se no escritor uma concepção desse espaço carregada de simbologia, que dialoga com uma tradição literária iniciada com Euclides da Cunha e solidificada com Guimarães Rosa.

Vicentini (1998) inicia seu artigo "O sertão e a literatura" partindo do estudo da origem da palavra sertão, vocábulo que, segundo ela, aponta sempre para um sítio oposto e distante de quem está falando. Tem-se, então, seguindo seu raciocínio, a formulação da primeira oposição básica litoral/sertão pelos portugueses, a partir do ponto de vista do mar, explicando-se o sentido popular de que o sertão é outro lugar, ou o lugar do outro. O sertão se estrutura na literatura pela ótica do colonizador, um ponto 
de vista distanciado que vê o outro como desconhecido e impenetrável, rude, iletrado, que vive no mundo desordenado, fora da lei.

Cordeiro (2003), ao discutir sobre como o sertão vem sendo historicamente apresentado na literatura brasileira, destaca que, ao ganhar relevância literária durante o romantismo, ele é tomado a distância, tratado como pano de fundo para mostrar questões que se acreditavam universais, mas que, na verdade, reproduziam clichês da escola, como amor, fidelidade, honra, coragem, heroísmo. Os valores e as qualidades atribuídos ao sertão sob uma perspectiva externa influenciaram não apenas questões temáticas e a caracterização das personagens - tipificadas como brasileiros autênticos mas também contaminaram a linguagem, transposta de uma tradição clássica já estabelecida para uma realidade muito estranha a ela. É apenas com a publicação de $O s$ sertões em 1902 que se inicia a complexificação do sertão a partir dele mesmo. O pesquisador afirma que, na obra de Euclides, como na de Rosa, o sertão deixa de ser cenário e passa a ser um universo dotado de movimento.

Em “A espera da volante”, Ronaldo Correia de Brito retrata o sertão em sua íntima ligação com o homem. Em um espaço onde o pensamento cartesiano e o progresso industrial não se fazem evidentes, onde a presença do Estado é tão rarefeita que se confunde também com aquele que oprime, personagens são criadas e justificadas por sua relação com a natureza e o espaço, esse espaço que, por distante, rude, iletrado, cria suas próprias leis e faz com que o tempo se repita; a linearidade do progresso é suplantada pela circularidade da existência que só vê razão de ser a partir da reatualização de hábitos e práticas. Brito constrói as personagens e a lógica do sertão carregadas de uma tensão antagônica, como a reforçar a contradição de uma injustiça social, mas também como a reconhecer a dualidade humana. Tal perspectiva reforça o aspecto contemporâneo de sua obra; não temos uma prosa que busca predominantemente discutir as mazelas sociais, o efeito afetivo e sensível é almejado, a partir da visão de um presente que se constitui pelo arcaico, pela procura da origem.

Vejamos como o espaço se apresenta e caracteriza as personagens. Desvinculado de um mero descritivismo, ele é apresentado na medida em que personagens e trama se constroem.

\section{Epígrafe: tradição religiosa e prenúncio do espaço}

Nossa análise do espaço parte da epígrafe escolhida pelo autor. Precede-se ao conto a citação de um trecho da Bíblia, referenciada como "profecia de Isaías 39,4". É uma passagem muito significativa, já que, assim como Ezequias, rei de Judá, que abriu inocentemente as portas de seu palácio a enviados do rei da Babilônia, nosso protagonista, o Velho, também abre sua casa a visitantes e lhes mostra os seus tesouros: neste caso, sua hospitalidade, sua compaixão e generosidade. No entanto, o trecho realmente profético do referido capítulo bíblico, sugerido pelo termo "profecia" e que dialoga ainda com maior vigor com o porvir da trama, se apresentará nos próximos versículos, nos quais o profeta Isaías anuncia a Ezequias: "Eis aí está que virão dias, e todas as coisas, que há na tua casa, e que teus pais entesouraram até o dia de hoje, serão tiradas para se conduzirem a Babilônia. Não ficará coisa alguma, diz o Senhor" (BÍBLIA, Isaías, 39, 6). O Velho abrigou em sua casa um assassino da região e a narrativa gira em torno da expectativa de chegar a volante policial para puni-lo por esse ato, destruindo tudo o que possui. "Estou pronto para qualquer encontro", dirá a 
personagem. Não se tem uma afirmação direta de que a volante o punirá, mas os seus métodos já são amargamente conhecidos pelos habitantes do sertão. No entanto, o que na passagem bíblica soa como imprudência do rei de Judá, fruto talvez de sua vaidade em mostrar seus tesouros, aqui o que se tem é uma personagem que vive a solidariedade e o amor ao próximo incondicionalmente, como ensinam os próprios textos bíblicos aos cristãos, mas ele sofrerá com a iniquidade humana. Interessante observar que o protagonista é apresentado como profeta, vislumbrando seu próprio fim: "De procurar ver, enxergava-se antes do acontecido. Como agora, quando o verde da camisa suada dos soldados era visível, e não havia mais dúvidas de que o esperado encontro, finalmente, estava para acontecer" (BRITO, 2009, p. 21).

\section{O espaço e a construção das personagens}

O cenário surge animizado na narrativa, mimetizando a tensão em que vivem as personagens: "Os sertões se abalavam nas passadas descalças dos assassinos, medrosos de deixarem sinais, e nas botas reiunas dos homens da justiça." (BRITO, 2009, p. 12). Sente-se o abalo do sertão a todo o momento pela tensão que se cria na trama: o Velho abrigou um suposto assassino, Chagas Valadão, que abusou da hospitalidade sertaneja, e a qualquer momento, sem julgamento ou ampla defesa, ele sofrerá a punição sem critérios aplicada pela volante. A mesma força policial que foi criada para proteger os sertanejos agora os amedronta e pune: "No princípio, os soldados tinham a simpatia e solidariedade de todos. Mais tarde, a crueldade dos seus atos foi conhecida e passaram a temê-los" (BRITO, 2009, p. 14). Observa-se que é uma intervenção externa, advinda do espaço urbano, marcado por suas leis (a volante veio da capital) que interfere na dinâmica do sertão e que se confunde com seu próprio malfeitor. Essencialmente, há aí uma contradição: o Velho será punido justamente por praticar a lei mais sagrada deste espaço: a hospitalidade. Nota-se que as outras personagens, Irineia e Luís Ferreira, advertem o Velho sobre a vinda da volante e temem seu futuro, mas não podem fazer nada, o medo os paralisa, assim como a tantos outros. A intervenção externa não respeita a lógica daquele espaço; o que parece a princípio dialogar com a cultura local, ignora as suas idiossincrasias, já que o Velho é figura respeitada pelos moradores da região. De certa forma, a volante trai a confiança dos sertanejos, que, ao chegar da capital, "muitos foram os que se apresentaram como voluntários, para ajudar na perseguição" (BRITO, 2009, p. 14). Os maus-tratos da terra criam um homem habituado ao castigo, com uma concepção mítico-religiosa de expiação de pecados cometidos secularmente:

$\mathrm{Na}$ marcha, os soldados aplicavam o chicote de couro cru. Os homens, habituados ao maltrato da natureza, recebiam aquele castigo, contritos de uma pesada culpa a expiar. Desde meninos, acostumavam-se à expiação. Toda dor era carpida em nome de algum pecado cometido por eles mesmos, ou pelos pais dos seus pais. As costas curvavam-se ao braço forte dos soldados. Um crime tinha sido cometido e todos deviam pagar. (BRITO, 2009, p. 20).

A simbiose entre o espaço e as personagens fica evidente na construção de Irineia e do Velho. De forma recorrente no conto - conta-se quatro vezes a alusão - o comportamento de Irineia é relacionado às fases da lua. "Irineia pensava na notícia. A lua era minguante e sua cabeça estava com todo o juízo [...]. Os dias de alvoroço haviam passado com a lua cheia. Cumprira o tormento de mulher atada à sina de uma loucura.". 
Chevalier e Gheerbrant (1999) afirmam que a lua simboliza o princípio feminino, assim como a periodicidade e a renovação. $O$ retorno às formas iniciais e a periodicidade sem fim fazem com que a lua seja, por excelência, o astro dos ritmos da vida. É a parte do primitivo que dormita em nós.

É a sensibilidade do ser íntimo entregue ao encantamento silencioso de seu jardim secreto, impalpável canção da alma, refugiado no paraíso de sua infância, voltado sobre si mesmo, encolhido num sono da vida - senão entregue à embriaguez do instinto, abandonado ao transe de um arrepio vital que arrebata sua alma caprichosa, vagabunda, boêmia, fantasiosa, quimérica, ao sabor da aventura (CHEVALIER; GHEERBRANT, 1999 , p. 564-565).

Irineia, mulher marcada pelos ciclos lunares, perambula pelo sertão. A personagem insere-se e despede-se da narrativa com o seu larilará que se ouve de longe, como uma criança que colhe seus brinquedos entre o que todos acreditam ser tralhas. Cantarolando a cantiga de sempre, Irineia caminha livre pelas estradas: "galhinhos de manjericão nos cabelos, fitas de cores nos braços [...] Uma cesta que nunca largava enchia-se do que ia encontrando pelos caminhos: molambos, pedaços de papel, xícaras sem aro, trapos de seda, caixinhas vazias de pó e ruge. Era tempo de se por bonita e andar" (BRITO, 2009, p. 16). Todos os seus traços faziam Irineia ser vista como louca pelos moradores. Apenas o Velho enxerga sua coerência: "Irineia, doida varrida para todos, mas sempre tão sã para o Velho" (BRITO, 2009, p. 11). Chevalier e Gheerbrant (1999) trazem a simbologia do louco em seu dicionário. Ele representa o que está fora do jogo do tarô, fora da cidade dos homens, fora dos muros. Nessa posição descentrada vive Irineia, que não tem uma casa para morar, dorme debaixo das árvores, e busca se proteger dos cães e também dos próprios moradores. Mas também o Velho parece simbolizar o louco em "A espera da volante". Os pesquisadores afirmam que "o inspirado, o poeta, o iniciado parecem loucos muitas vezes, por algum aspecto do seu comportamento. Nada parece mais louco do que a sabedoria para aquele que não conhece outra regra que o bom-senso (CHEVALIER; GHEERBRANT, 1999, p. 559).

O Velho é o único no sertão que desafia o bom senso e abriga o suposto assassino. "A fama da casa ia longe e isso, talvez, tivesse atraído Chagas Valadão na sua fuga. Quem iria dar guarida a um assassino, com volante policial no seu rastro? Só o Velho, ou outro que tivesse interesse em dinheiro" (BRITO, 2009, p. 14). Sabe-se que não é o espírito mercenário que o move. Reforça-se em vários momentos da narrativa sua acolhida incondicional às pessoas, uma generosidade que ultrapassa a precaução corrente, com uma serenidade adquirida pelo aprendizado. "Ele esperava a visita dos soldados. A vida toda fora um espreitar de armadilhas, prontas a apanhá-lo nos seus entrançados. Habituara-se ao perigo. A paz de sua casa, as portas e janelas abertas existiam porque espantara o medo dali" (BRITO, 2009, p. 20). Chevalier e Gheerbrant (1999) citam a lenda dos peúles, povo seminômade de origem africana, ao dizer que há três espécies de loucos: o que tinha tudo e tudo perdeu bruscamente; o que não tinha nada e tudo adquire sem transição; e o louco, doente mental. Mas ao final, complementam: "Poder-se-ia acrescentar um quarto tipo: o que tudo sacrifica para adquirir sabedoria, o iniciado exemplar. [...] O louco está fora dos limites da razão, fora das normas da sociedade" (BRITO, 2009, p. 560). O Velho parece representar o iniciado, aquele que busca a sabedoria. Sua figura no sertão é uma incógnita, suscita a curiosidade e a incompreensão dos moradores, pois sua bondade ultrapassa os limites do 
humano: "O mistério de sua vida despertava boatos, contavam lendas [...] Falava-se de um crime cometido na juventude, um impulso de ódio em terra muito distante. Do desejo de purgá-lo teria nascido a bondade, a compreensão para os desvalidos (BRITO, 2009, p. 15).

A imagem do Velho como alguém de imensa bondade tangenciando com uma face cruel reflete uma forma de pensamento popular que observa no homem a dualidade de seus sentimentos, ilustrando a convivência, em cada ser humano, de forças antagônicas. É o que nos ensina um dos maiores narradores da nossa literatura. Em Grande sertão: veredas, Riobaldo narra ao seu interlocutor duas diferentes histórias em que as personagens demonstram que em si convivem a maldade e a bondade: Aleixo, homem cruel que, como paga de um assassinato sem causa, tem os filhos tornados cegos e passa a ser um homem de Deus, caridoso em todas as horas de sua vida; e Pedro Pindó juntamente com sua esposa, pessoas de bem que com a justificativa de castigar o filho por suas maldades, passam a criar nisso uma diversão. $O$ narrador conclui: "Explico ao senhor: o diabo vige dentro do homem, os crespos do homem [...] Solto, por si, cidadão, é que não tem diabo não [...] Arre, ele está misturado em tudo. Que o que gasta, vai gastando o diabo dentro da gente, aos pouquinhos, é o razoável sofrer" (ROSA, 2006, p. 10-11). O Velho gastaria o diabo dentro de si flagelando-se.

Interessante observar que o desprendimento do Velho é representado em sua ligação com a casa. A expressão "portas abertas" é uma frequência no texto. Ela surge cinco vezes, além de mais duas variações, nas quais é substituída a palavra "portas" por "casa" e "braços". Mais uma vez nos reportamos a Chevalier e Gheerbrant (1999) para elucidar o que a porta traz de simbologia. Eles nos dizem que a porta tem, além de outros significados, uma dimensão escatológica. Como local de passagem, de chegada, torna-se símbolo da iminência da possibilidade de acesso a uma realidade superior. $\mathrm{O}$ retorno de Cristo é anunciado e descrito como um viajante que bate à porta. E cita duas passagens bíblicas: "o Filho do Homem está à porta" e "Eis-me, estou à porta e bato. Se alguma pessoa ouvir a minha voz e abrir a porta, entrarei e farei a Ceia com ela e ela a fará comigo (BÍBLIA apud CHEVALIER; GHEERBRANT, 1999, p. 736). Espaço e personagem surgem, então, construídos de forma imbricada.

O Velho se configura a partir das metáforas que se constroem em sua relação com a casa. Ela materializa a generosidade do Velho, é a localização da casa que se procura para receber as benzeduras, é por meio dela que o Velho pratica o amor ao próximo, oferecendo-lhes abrigo incondicionalmente. Mais do que um abrigo, transpassar as portas da casa é também entender a alma do seu dono, o que nem todos podem fazer. Analisemos mais indícios dessa relação.

Por meio da vivência das personagens, conhece-se um pouco mais a casa do Velho e o que ela representa aos moradores da região. Sobre Irineia, o narrador diz: "Desejava descansar das noites dormidas debaixo das árvores, sujeita ao frio e aos assaltos do medo. $\mathrm{O}$ alpendre oferecia um chão limpo e cheirosas vigas de umburana, onde escorar o corpo moído" (BRITO, 2009, p. 12). A aridez do espaço que maltrata Irineia reflete-se também na aridez das pessoas que provocam ainda mais sofrimento para a personagem: "Irineia aparecia sempre, escapada dos cães das estradas, da perseguição dos homens que queriam deitar com ela, do ciúme das mulheres abandonadas pelos maridos" (BRITO, 2009, p. 16). Só a casa do Velho era abrigo para ela: "Havia o mundo, onde cumpria sua sina de loucura e, num canto deste mundo, a 
casa do Velho, repouso dos medos" (BRITO, 2009, p. 16).

A casa confunde-se com seu dono e sua simbologia reflete seu espírito. "Havia o alpendre na frente, onde o Velho ficava sentado e, atrás, a casa de três vãos, grande como a alma de um homem que vivera muito. Ninguém sabia quem existira primeiro, se o Velho ou a casa" (BRITO, 2009, p. 12). Sua existência é vista de tal forma em uma simbiose com a natureza e o espaço que ambos se confundem: "O Velho plantara-se ali, como se tronco fosse, e olhava-se para ele como para o juazeiro que dava sombra por dever de natureza, sem que nunca alguém lhe agradecesse" (BRITO, 2009, p. 15). Entender a alma do Velho e suas motivações não é conquista de muitos. Diz-se com frequência das pessoas que passam a sua porta ou achegam-se a seu alpendre, mas poucos adentram a casa, ultrapassam a porta. As portas estão sempre abertas, mas nem todos serão capazes de transpassá-las. "A casa possuía muitas portas e janelas, sempre abertas. Quem queria, entrava. Uns não avançavam além do alpendre. Ao coração de uma casa, chega-se de olhos fechados (BRITO, 2009, p. 13). Ele abrigava a muitos, mas a referência é feita ao alpendre: "Eram tantos os que passavam na sua porta, dormiam no seu alpendre, falavam pra ele ouvir" (BRITO, 2009, p. 15). Luís Ferreira é uma das personagens que adentra a casa. Por ter-lhe chegado ao coração, não busca o bom senso no ato do Velho de receber o assassino: "Adiantaria fazer perguntas?" (BRITO, 2009, p. 19). Sua relação com o protagonista é antiga e inicia-se, assim como acontece com Chagas Valadão, em momento de necessidade. Por meio de uma analepse, o narrador traz para a narrativa o momento do primeiro encontro dos dois. Indicada por um menino na estrada, pois procurava um benzedor para curar um mal que atacara os cascos do cavalo, Luís Ferreira encontra a casa sem o dono, portas e janelas abertas: "No fogão de barro, uma panela fervendo. Luís Ferreira apeou-se e esperou.". Temos, em seguida, o momento de descrição do Velho, em íntima relação com a terra:

Uma cascata de chocalhinhos precedeu o Velho. A calça e a camisa de alvo madapolão brilhavam no sol poente. As barbas chegavam à cintura e só a poeira disfarçava o seu branco. Vinha devagar, falando aos animais como se fossem seus filhos. Os pés descalços plantavam-se no chão seco. Com um riso manso, saudou o hóspede e pediu para se sentar. Entre o vapor do café fumegante, olharam-se nos olhos e nasceu, desse instante, a amizade que os uniria (BRITO, 2009, p. 18).

O espaço é descrito de forma integrada às ações e à construção das personagens. Não há momentos de descrição do cenário sertanejo desvinculado de uma natureza humana. O Velho, como um juazeiro que dá sombra como dever da natureza, aqui é descrito como um elemento da terra, em íntima relação com ela, com seus bichos. Como uma espécie de visão profética, precedido de um chocalho, barba longa e branca e com vestes que irradiam luz, cria-se uma imagem na mente do leitor que o reporta a um tempo antigo, primordial. Em algumas culturas, a repercussão do sino, aqui representado pelo chocalho, é a repercussão do poder divino na existência: a percepção do ruído do sino dissolve as limitações da condição temporal; no budismo, as vozes divinas assemelham-se ao som de um sino de ouro (CHEVALIER; GHEERBRANT, 1999 , p. 835). É também característica do homem primitivo sua relação com a natureza de modo a ver-se como elemento da paisagem. A natureza também está ligada com o destino das personagens, de modo a sentir diretamente as injustiças do ser humano. Ao narrar a chegada dos soldados para castigar o Velho, o sertão se abriria em desgraça: "As árvores revelariam sinais. Com certeza, perderiam o brilho verde das suas folhas. $\mathrm{E}$ as vacas, que tudo pressentem, reteriam o leite nos peitos inchados. Como praga de 
seca, os homens passariam matando, amofinando o que caísse debaixo da força maldita dos seus olhos" (BRITO, 2009, p. 21). No livro Mito e realidade, Eliade (2011, p. 34) nos diz que "o homem das sociedades tradicionais sente a unidade fundamental de todas as espécies de 'obras', sejam elas de ordem biológica, psicológica ou histórica.”.

Outro dado ao qual é importante nos determos é o fato de o protagonista ser a única personagem não nomeada no conto, sendo apenas chamada de o Velho. A inicial maiúscula da palavra indica sua singularização e faz com que esse seja o traço que o mais representa. Com uma existência que se sugere eternizada - o velho parece ter sempre estado ali - a velhice é um sinal de sabedoria e virtude, "uma prefiguração da longevidade, um longo acúmulo de experiência e de reflexão, que é apenas uma imagem imperfeita da imortalidade. [...] ser um velho é existir desde antes da origem; é existir depois do fim desse mundo" (CHEVALIER; GHEERBRANT, 1999, p. 934). Talvez por esse motivo, por não estar apegado a sua materialidade, o Velho é capaz de entender sua vivência a partir de valores transcendentes. "Que poderiam contra aquele homem que olhava sereno para frente, como quem tudo vê?”" (BRITO, 2009, p. 13).

Mas é Chagas Valadão que, ao relatar seu crime e arrependimento, trará à lembrança do Velho acontecimentos dolorosos. "O Velho calara e olhava em frente. Desde a passagem de Chagas Valadão, tornara-se mais quieto, como se uma onda trouxesse o entulho de um tempo apagado da memória. Abriam-se arcas pesadas, de pertences esquecidos" (BRITO, 2009, p. 13). O Velho recorda o passado e olha "em frente". A recordação faz com que reviva o passado, mas de alguma forma o reporta para o futuro. Eliade (2011) diz que a memória desempenha papel fundamental, pois através da rememoração, da anamnesis, há uma libertação do Tempo. É uma técnica associada à concepção arcaica de reatualização, a importância de se conhecer a origem e a história de algo para poder dominá-lo: “a memória é considerada o conhecimento por excelência. Aquele que é capaz de recordar dispõe de uma força mágico-religiosa ainda mais preciosa do que aquele que conhece a origem das coisas" (ELIADE, 2011 p. 83).

$\mathrm{O}$ ato de recordar, rememorar, é uma das práticas do Velho. Por meio de um ritual de penitência, que diz ser promessa feita pela mãe para que ele escapasse de moléstia grave, a personagem assombra os moradores da região:

E ele era penitente de cumprir via-sacra de sofrimento e sangue, repetir o calvário todas as Semanas Santas ou quando não chovia. Vestia uma opa negra, saía cantando benditos e esmolando nas portas. O rosto coberto com um pano, por pudor de ser reconhecido. Em cada porta se cortava nas costas com um cacho de lâminas, até que o sangue molhasse o chão. As rezas cantadas no escuro da noite assombravam as pessoas, tementes de castigos que não compreendiam (BRITO, 2009, p. 15-16).

Seu ritual assemelha-se à via crucis repetida também pelos católicos em ocasião da Semana Santa e o apelo nas casas, a representação de suas estações, rememorando o sofrimento de Jesus ao carregar sua cruz até o Calvário. O pedido de esmola com o rosto coberto parece apelar à generosidade das pessoas. "Jesus às vezes se disfarça de mendigo pra testar a bondade dos homens", dirá Rosinha em $O$ auto da compadecida.

Eliade (2011) diz que embora o cristianismo afaste-se de um Tempo cósmico, que o Mistério da Encarnação se dê em um Tempo histórico, ele não pode ser reduzido a sua historicidade. Ainda que representado na História, o drama possibilitou a salvação; "consequentemente, existe apenas um meio de obter a salvação: repetir 
ritualmente esse drama exemplar e imitar o modelo supremo, revelado pela vida e pelo ensinamento de Jesus. Ora, esse comportamento religioso faz parte do pensamento mítico autêntico" (ELIADE, 2011, p. 146).

\section{Do sertão de Inhamuns para a literatura: Chagas Valadão}

Uma nota muito interessante é a identificação de Chagas Valadão como figura histórica do sertão de Inhamuns. Em consulta à hemeroteca digital do CNFCP (Centro Nacional de Folclore e Cultura Popular), encontramos uma matéria do Correio do Ceará, de 25 de fevereiro de 1967, intitulada "Reside nos Inhamuns o melhor rastejador do nordeste". Nela, tem-se uma entrevista com Francisco Valadão de Souza, ou melhor, Chagas Valadão, como era conhecido na região. Relata-se a "ciência" de toda a família de "ler corretamente no rasto do ser humano", embora seja ele reconhecido como o mais perito em decifrar tão complicados sinais. Na época com 44 anos, "caboclo desempenado, hercúleo, pele escura, físionomia de branco, típico ameríndio", Valadão conta suas peripécias e a dificuldade de exercer tão perigosa atividade. "Já tendo servido até em diligências policiais, como espécie de detetive primitivo", o rastreador relata que "nunca se sentiu satisfeito em desempenhar tão espinhosas missões. Não faz trabalho pago em perícia desse quilate, que tem sido exatíssimas. Criam-lhe, no entanto, irreconciliáveis inimizades e com gente da pior espécie". Mas o rastreador evidencia a sina do sertanejo em se sujeitar a forças superiores a ele: "Repúgna sempre caçar criminosos que lhe têm trazido múltiplos dissabores. Todavia, quem vive neste mundo de meu Deus não pode fazer nem o que quer" (CORREIO DO CEARÁ, 1967). Em documentário dedicado à família Valadão, lançado em 2013, o longa metragem do cineasta Marcus Moura, $O$ último rastro, relembra o assassinato do irmão do delegado Inacio Feitosa, o futuro chefe da polícia do Ceará, morto em Parambu na década de 1960, que foi desvendado com a ajuda dos irmãos Chagas, Assis e Zé Valadão. O criminoso foi encontrado pelos Valadão por rastro deixado por ele em um forró. $\mathrm{O}$ assassino estava a $200 \mathrm{~km}$ de distância. Uma questão interessante no documentário é a recorrência, no discurso dos entrevistados, de assinalar a crença de que tais rastreadores utilizavam na verdade de feitiço para descobrir tais paradeiros, o que reforça a permanência de uma compreensão do mundo a partir de elementos sobrenaturais, míticos na região, esse sertão que continua a construir personagens lendárias.

Aqui temos outro traço contemporâneo na prosa regionalista de Ronaldo Correia de Brito. Valorizando o aspecto performático, a arte ressignifica a realidade, recriada pelo texto literário. Não mais apenas como denúncia, fatos históricos prestam-se a uma nova leitura, descompromissados de veracidade. Recriado pelo escritor cearense, a personagem adentra a ficção em outra posição: não mais quem rastreia, mas quem é rastreado.

A questão da dualidade e da contradição, presentes na representação de Chagas Valadão, também pode ser destacada entre outros elementos do conto. Personagens e instituições, de modo geral, carregam este antagonismo: a volante, que traz a ordem, pratica crimes; o sertão, que valoriza a hospitalidade, castigará aquele que a praticou; Irineia, doida varrida, é a que traz notícia merecedora de fé; o Velho, homem bom, parece carregar um passado marcado pela culpa. A natureza humana é em sua essência dual. 


\section{O tempo e as concepções míticas no conto}

Embora não estejamos diante do mito tal qual se utilizavam os povos primitivos, evidenciamos como tais concepções estão presentes no conto. Muitas são as recorrências à cultura católico-cristã: a epígrafe, o ritual de penitência referenciado pela via-sacra, a simbologia da expressão "portas abertas" reiterada na narrativa são as que evidenciamos ao longo de nossa análise. Como apresenta Eliade (2011), ainda que o Cristianismo aceite o tempo linear da história, com a concepção de que o mundo foi criado uma única vez, com um só evento de Encarnação no tempo histórico, havendo apenas um Juízo, a experiência religiosa do cristão baseia-se na imitação de Cristo como modelo exemplar, no tempo litúrgico da vida, morte e ressureição do Senhor, e na contemporaneidade do cristão com o illud tempus, iniciando-se com o nascimento em Belém e terminando, provisoriamente, com a Ascenção. Ora, conclui o pesquisador, "a imitação de um modelo transumano, a repetição de um enredo exemplar e a ruptura do tempo profano mediante uma abertura que desemboca no Grande Tempo, constituem as notas essenciais do "comportamento mítico" (ELIADE, 2011, p. 147). Evidenciamos, em alguns momentos deste estudo, que o pensamento mítico permeia a narrativa e constrói o protagonista. Sua descrição é marcada por uma aura transcendental que se une à prática de rituais de penitência que reatualizam o flagelo de Cristo. Mas como se dão as marcas linguísticas dessa visão de mundo na categoria do tempo?

Benedito Nunes (1995, p. 66-67), em O tempo na narrativa, nos diz que, a rigor, não existe um tempo mítico, porque o mito abole a sucessão temporal. "Será mais correto dizer que o mito relata um acontecimento genérico que não cessa de produzir-se: uma origem coletiva [...] e a repetição dessa origem [...] num presente intemporal, que se insinua na linha mutável da vida individual". Mas como esse fenômeno ocorre em um discurso narrativo se assistimos em tal discurso, justamente, a existência das personagens no tempo é agora nossa questão. Ele lembra que, considerando que no mundo imaginário qualquer modalidade temporal existe em função da sua representação na linguagem, o tempo da obra, assim como o espaço, é um dos correlatos do discurso. "Do discurso, enquanto linguagem concreta, efetuada, cabe lembrar a linearidade ínsita: como 'meio formado de unidades consecutivas', não pode ordenar, senão sucessivamente, todas as representações, mesmo as simultâneas." (NUNES, 1995, p. 25). Castagnino (1970) ressalta que o procedimento natural do conto consiste na narração de fatos, encadeando-os no tempo, sendo impossível ao narrador negá-lo dentro da estrutura de seu relato. Toda narração sempre será sua evocação, isto é, sua memória, sua recuperação do passado. "Igualmente será evocação a narração de antecipações e profecias, pois ao relatá-las quem as formula já as viu consumadas como antecipações e profecias" (CASTAGNINO, 1970, p. 56).

$\mathrm{O}$ efeito conseguido neste conto é a criação de uma atmosfera marcada pelo movimento cíclico, repetitivo. Em termos de diegese, poucos são os acontecimentos. Narrado em medias res, o conto inicia com o anúncio de uma notícia de fé trazida por Irineia. Não se tem, na verdade, uma sucessão rica de fatos. O Velho continua recebendo os viajantes em seu mesmo ritmo habitual - "Não havia pressa. O escuro não teria irremediavelmente que suceder o claro?" - e a volante prossegue em sua busca pelos fugitivos, amedrontando e maltratando a população. Enquanto o Velho velhava (tomando de empréstimo o neologismo de Rosa), balançando a cabeça, rindo manso, comendo uma coalhada gorda com farinha, esperando em sua cadeira de balanço, a volante marcha. Ao narrar a partida de Irineia, o narrador nos relata: "O Velho ficava 
para trás. Outros passariam pela casa, como todos os dias e como sempre" (BRITO, 2009, p. 17). Em busca de pistas linguísticas para elucidar nosso questionamento, analisamos a recorrência dos tempos gramaticais no conto. Há uma predominância expressiva, $56 \%$, de verbos conjugados no pretérito imperfeito do indicativo, enquanto são contabilizados apenas $20 \%$ de verbos no pretérito perfeito. Os verbos no pretérito perfeito acumulam-se, em grande proporção, nas inserções de discurso direto. A voz do narrador pouco usa tal tempo verbal. Tem-se, ainda, $15 \%$ dos verbos no futuro do pretérito, $5 \%$ no pretérito mais-que-perfeito, $3 \%$ estão conjugados no tempo presente e $1 \%$ no passado composto.

Nunes (1995, p. 39-40), ao discutir sobre o efeito de sentido atribuído aos tempos gramaticais, cita Weinrich dizendo que os tempos verbais na narrativa exercem função diferente da que os gramáticos pensaram em relação à divisão do tempo, situando o leitor ou o ouvinte no processo comunicacional da linguagem. O pretérito perfeito, o imperfeito e o mais-que-perfeito indicam uma situação de locução narrativa, orientando-nos no mundo narrado, das coisas distantes, não imediatas, enquanto o presente, o passado composto e o futuro configuram uma situação discursiva, de comentário, reclamando uma tensão no uso da linguagem, que aproxima o locutor do objeto. As duas situações de locução, no entanto, não são estanques, interpenetrando-se. Pouillon (1974), assim como Nunes e outros teóricos, questiona-se sobre o uso frequente do pretérito na narrativa ficcional, mesmo quando quer se reproduzir o presente e até mesmo o futuro. Assinala que o verdadeiro sentido romanesco do pretérito imperfeito não é temporal, mas espacial, distanciando-nos do que estamos olhando. "Não quer isto dizer que a ação esteja passada, pois o que se pretende é, pelo contrário, fazer-nos assistir à mesma: significa que ela está diante de nós, à distância, sendo justamente por isto que podemos presenciá-la" (POUILLON, 1974, p. 115).

Em “A espera da volante”, cuja predominância é o pretérito imperfeito, temos um andamento vagaroso, com poucas sequências retrospectivas, carecendo de especificações cronológicas. A permanente atualidade do narrar, encobrindo a voz do narrador, retira do pretérito épico a função indicativa da anterioridade da história, como passado para quem narra.

Um indício de ênfase à questão do tempo é o título do conto. Uma primeira leitura pode nos levar a entender "A espera" como uma locução adverbial de tempo, o que sugeriria o aspecto de expectativa pela chegada da volante: alguém, provavelmente o Velho, estaria à espera. No entanto, sem o acento grave, temos um sintagma nominal. Dentre as acepções dadas pelo Novo Dicionário Aurélio da Língua Portuguesa (FERREIRA, 2004), identificamos dois significados da palavra "espera" que parecem possíveis ao contexto: 1. Demora, dilação; 2. Emboscada, cilada, tocaia. Sendo, neste caso substantivo, a ênfase é dada ao ato em si. Ligando-o ao tempo, tem-se o olhar para a demora, para a prorrogação, o adiamento da volante (ampliando os significados que o termo dilação nos dá). Deixando de ser locução adverbial, que provoca a sensação de expectativa, de iminência, para ser um sintagma nominal, tem-se o fato, é dada sua existência. É assim, como algo dado, que o Velho parece encarar a ação da volante e como se dá o relato da história. Sem uma trama movimentada, a narrativa se constrói apresentando a existência do Velho e sua dinâmica que se repete a cada dia. 


\section{Considerações finais}

A essência da arte é a sua liberdade criativa que está vinculada, muitas vezes, com a ruptura de paradigmas, altamente valorizada no cenário literário. No entanto, o vínculo com a tradição não necessariamente significa ausência de renovação, e isso podemos constatar em Ronaldo Correia de Brito. Ligado à tradição de um realismo regionalista, o escritor não se resume a representar as mazelas do sertão nordestino, motivo que levou o movimento a perder credibilidade entre os críticos e os próprios escritores contemporâneos, mas busca, através da expressão artística, explorá-lo em íntima ligação com seres que nele vivem e interagem, entendendo-os como organismos interdependentes. A concepção do homem primitivo que ainda sobrevive no De-Sertum, no lugar incerto, desconhecido, estranho aos olhos do outro, é retratada de forma a compor os elementos narrativos, dando qualidade às suas produções. A violência e a crítica à ausência do Estado, recorrentes no autor, presentificam-se no conto, assim como a brevidade das frases, a linguagem sintética e direta, as frases lapidares. "Ao coração de uma casa, chega-se de olhos fechados", dirá o narrador. Partindo da ideia de dualidade como expressão da condição humana e das relações sociais, o antagonismo do homem e da terra está presente, dialogando com figuras históricas, recriando-as pelo olhar da literatura, ao gosto da nova ficção regionalista. A tradição oral é reatualizada pelo tempo cíclico instaurado na narrativa e a influência das narrativas bíblicas surge já na epígrafe e permeia toda a figura do protagonista, em uma harmonia com a religiosidade do sertanejo, conhecida por todos. Seja dialogando com Guimarães Rosa pelo imaginário do sertão com sua violência e abandono, ou com Graciliano Ramos por meio de sua escrita objetiva e sintética, Ronaldo Correia de Brito vem construindo sua trajetória em diálogo com a tradição, mas também com o persistente anseio, reconhecidamente genuíno, do escritor contemporâneo de retratar o universo sertanejo para além de suas moléstias e cenário desértico, privilegiando o efeito afetivo e sensível e trazendo ao texto a experiência simultânea de temporalidades diferentes.

\section{REFERÊNCIAS}

AGAMBEN, G. O que é contemporâneo? e outros ensaios. Tradução de Vinícius Nicastro Honesko. Chapecó: Argos, 2009. p. 55-72.

ALMEIDA, C. E. O romance regionalista dos anos de 1930. In: SALES, G.; SOUZA, R. A. (Org.). Literatura brasileira: região, nação, globalização. Campinas: Editora Pontes, 2013. p. 31-41.

ARRIGUCCI, D. Jr. Tempo de Espera: posfácio. In: BRITO, R. C. Faca. São Paulo: Cosac Naify, 2009.

BÍBLIA. Português. Bíblia sagrada. Tradução de Padre Antônio Pereira de Figueiredo. São Paulo: Editora Iracema, 1979.

BRITO, R. C. Cântico para um mundo em dissolução. Jornal O Povo, 9 mai. 2005. Disponível em: $\quad<\mathrm{http}: / / \mathrm{www} . j o r n a l d e p o e s i a . j o r . b r / e c a r v a l h o 2 . h t m l>. \quad$ Entrevista concedida a Eleuda Carvalho. Acesso em: 10 ago. 2016.

. Faca. São Paulo: Cosac Naify, 2009. 
CASTAGNINO, R. Tempo e expressão romanesca. Tradução de Luiz Aparecido Caruso. São Paulo: Mestre Jou, 1970.

CENTRO NACIONAL DE FOLCLORE E CULTURA POPULAR. FILHO, J. F. Reside nos Inhamuns o melhor rastejador do nordeste. Fortaleza: Correio do Ceará, 25 fev. $1967 . \quad$ Disponível em: $<$ http://docvirt.com/docreader.net/DocReader.aspx?bib=tematico\&pagfis=41120\&pesq $=>$. Acesso em: 10 ago. 2016.

CHEVAlIER, J.; GHEERBRANT, A. Dicionário de símbolos: mitos, sonhos, costumes, gestos, formas, figuras, cores, números. Rio de Janeiro: José Olympio, 1999.

CORDEIRO, M. R. Metamorfoses do sertão: termos de comparação entre Euclides da Cunha e Guimarães Rosa. In: SEMINÁRIO INTERNACIONAL GUIMARÃES ROSA (2001: Belo Horizonte). Veredas de Rosa II/organização Lélia Parreira Duarte et al. Belo Horizonte: PUC Minas, CESPUC, 2003.

ELIADE, M. Mito e Realidade. São Paulo: Perspectiva, 2011.

FERREIRA, A. B. H. Novo Dicionário Aurélio da Língua Portuguesa. 3. ed. Curitiba: Positivo, 2004.

LEONEL, M. C.; SEGATTO J. A. O sertão literário na contemporaneidade: Guimarães Rosa e Ronaldo Correia de Brito. Revista Estudos Linguísticos, São Paulo, v. 39 (1), p. 1035-1044, 2010.

NUNES, B. O tempo na narrativa. 2. ed. São Paulo: Ática, 1995.

POUILLON, J. O tempo e o romance. São Paulo: Cultrix; Edusp, 1974.

RODRIGUES, R. R.; GRÁCIA-RODRIGUES, K. Fortuna e infortúnios do regionalismo. In: SALES, G.; SOUZA, R. A. (Org.). Literatura brasileira: região, nação, globalização. Campinas: Editora Pontes, 2013. p. 263-290.

ROSA, J. G. Grande sertão: veredas. Rio de Janeiro: Nova Fronteira, 2006.

SANTOS, J. S. Faca e seus cortes - o sertão trágico e feminino de Ronaldo Correia de Brito. 2014. 133 f. Dissertação (Mestrado em Estudos de Linguagens) - Universidade do Estado da Bahia, Salvador, 2014. Disponível em: <http://www.ppgel.uneb.br/wp/wpcontent/uploads/2014/04/santos_joelson.pdf>. Acesso em: 12 jun. 2017.

SCHOLLHAMMER, K. E. Ficção brasileira contemporânea. Rio de Janeiro: Civilização Brasileira, 2009. (Coleção contemporânea: Filosofia, literatura e artes).

VICENTINI, A. O sertão e a literatura. Revista Sociedade e Cultura, I (1), p. 41-54, $1998 . \quad$ Disponível em: $<$ http://www.revistas.ufg.br/index.php/fchf/article/view/1778/2139>. Acesso em: 10 ago. 2016.

Recebido em: 15/08/2016

Aprovado em: 17/02/2016 